\title{
Comparison between Serum Aldosterone Levels in Class I-II and Class III-IV Functional Heart Failure Patients
}

\author{
Taufik Indrajaya**, Rizki Darmawan ${ }^{1}$, Erial Bahar ${ }^{2}$ \\ ${ }^{1}$ Department of Internal Medicine, Faculty of Medicine, Universitas Sriwijaya, Palembang, Indonesia; ${ }^{2}$ Department of Anatomy, \\ Faculty of Medicine, Universitas Sriwijaya, Palembang, Indonesia
}

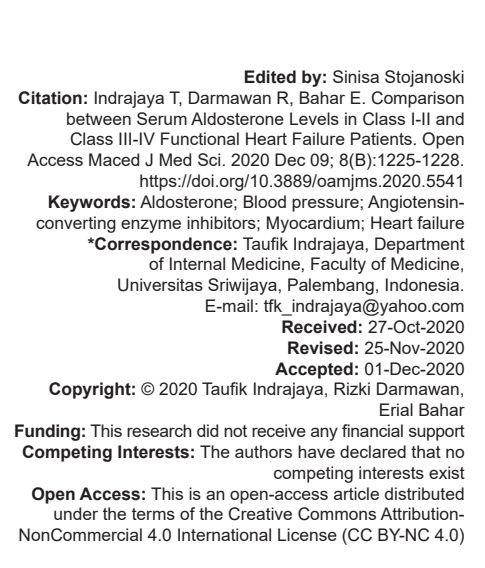

Introduction

The prevalence of heart failure (HF) in developed countries is around $1-2 \%$ of the entire population. The incidence increases with age, with an increase of 20/1000 individuals at the age of 65-69 years and more than $80 / 1000$ individuals beyond 85 years old [1]. Patients with HF often require hospitalization because of worsening symptoms. More than 1 million patients are treated for HF each year. Reports show that the average rate of rehospitalization in the $1^{\text {st }}$ month is around $25 \%$, and the average rate of rehospitalization in 3 months and 1 year is 30 and 50\% [1], [2], [3]. Pharmacological therapy is a significant component of HF management, which includes angiotensin-converting-enzyme inhibitors (ACEls), angiotensin II-receptor blockers (ARB), $\beta$-blockers, digoxin, diuretics, and aldosterone antagonists. Hydralazine and nitrate can also be given in some cases. ACEls and $\beta$ blockers have become standard therapy in all patients with systolic HF, with aldosterone antagonists and hydralazines/nitrates, which are only recommended in individual patients [4], [5].

Aldosterone is a mineralocorticoid that is synthesized by the adrenal, cardiac, and vascular glands and provides pleiotropic effects on these organs. The role of aldosterone in the pathophysiology of cardiovascular disease has long been known. Aldosterone is a neurohormonal part of the reninangiotensin-aldosterone system (RAAS) component that is responsible for the regulation of blood pressure, peripheral resistance, fluid, and electrolyte regulation. Aldosterone also plays a role in the occurrence of heart muscle fibrosis directly through mineralocorticoid receptors. Increased synthesis of aldosterone is stimulated mainly by angiotensin II (AT2) through the angiotensin-1 (AT1) receptor in the adrenal gland glomerulus zone cells. It is also encouraged by the hormone adrenocorticotropic hormone, potassium ions (hyperkalemia), endothelin, prolactin, vasopressin, catecholamines, acetylcholine, prostaglandins, and nitric oxide [5]. In HF, aldosterone plays a role in the initiation and development of its disease. During congestive HF, the initial reduction in cardiac output stimulates neurohormonal compensatory systems, such as the sympathetic nervous system and RAAS, which in turn exerts additional stress on the heart muscle. From several studies found a decrease in AT2 levels with ACEIs, ARBs, or a combination. Still, both are not enough to inhibit aldosterone production; this is known as "aldosterone escape." A study showed that $24 \%$ of patients taking ACEls had elevated serum aldosterone levels. The cause of a secondary 
increase in plasma aldosterone levels in patients who have received ACE blockers is unclear, but it may be an "escape phenomenon" of ACE blockers. Alternative pathways from the formation of AT2 can encourage increased production of AT2 so that there remains an increase in aldosterone levels after the enzyme conversion is inhibited. The initial treatment strategy focuses on reducing AT2 by administering ACE inhibitors because it is suspected that ACEIs can suppress the production of AT2 and aldosterone. However, several studies have shown that ACEIs and AT1 blockers only temporarily reduce aldosterone levels. There are several hypotheses that an increase in aldosterone levels results from the non-ACE pathway and the activation of the ACE-2 [6], [7], [8], [9], [10].

There are no specific studies on the comparison of serum aldosterone levels in patients with Class I-II functional HF with Class III-IV functional HF who consume ACEIs/ARBs. This study seeks to explore the comparison of aldosterone levels between Class I-II functional HF and Class III-IV HF to optimize therapy in cases of HF.

\section{Methods}

The design of this study is a quantitative observational study with a cross-sectional approach. This study was conducted at the Department of Internal Medicine Dr. Moh Hoesin Hospital in Palembang, Indonesia, where the study sample was all patients with HF in the Department of Internal Medicine who met the inclusion and exclusion criteria. The inclusion criteria were all patients diagnosed with outpatient functional I-II functional HF based on clinical symptoms, physical examination, and electrocardiography (ECG), as well as the history of consuming ACEls/ARB. All patients are willing to join the research by signing informed consent. Exclusion criteria are patients with chronic kidney failure, patients suffering from primary hyperaldosteronism or thyroid disease or liver disease, patients undergoing treatment with anti-aldosterone/ spironolactone, patients with myocardial infarction, and patients with chronic obstructive pulmonary disease and cor pulmonale.

A total of 32 subjects were included in this study using the consecutive sampling technique. Submission of subjects was conducted from December 1, 2019 to December 31, 2019. The ethics committee approved this study of the Faculty of Medicine of Universitas Sriwijaya with registration number 278/kptfkunsri-rsmh/2019.

The independent variable in this study is serum aldosterone levels, with the dependent variable being functional HF Class I-II and III-IV who consume ACEIs/ ARB. HF, according to the New York Heart Association (NYHA), a functional class is divided into four categories based on complaints of occurrence of shortness of breath. Class I, there were no complaints of shortness of breath even with substantial activities. Class II, if there are complaints of shortness of breath when doing rather strenuous activities such as climbing stairs or walking $100 \mathrm{~m}$. Class III, if there are complaints of shortness of breath when doing light activities or daily activities such as sweeping the house, bathing, and wearing clothes. Class IV, if there are complaints of tightness at rest or lying on their backs, the patient needs a pillow to raise his head. While confounding variables are body mass index (BMI), age, sex, hypertension, kidney disease, impaired liver function, hyperkalemia, hypernatremia, smoking, and dyslipidemia.

Data management and analysis are performed using the SPSS version 22.0 for Windows program. The results are described in the form of narratives, tabulations, diagrams, or pictures. Bivariate analysis was performed as a comparative analysis of serum aldosterone levels between Class I-II functional HF and Class II-IV functional HF using an unpaired t-test. Analysis to control for confounding variables uses a logistic regression test.

\section{Results}

Table 1 shows the baseline status and laboratory characteristics of the study subjects. The majority of subjects are male, age more than 55 years, the majority of high school and college-educated with the majority of labor and entrepreneurial work. The majority of participants smoke, with the etiology of most of the HF being due to hypertensive heart disease (HHD) and the prevalence of dyslipidemia and having a BMI of more than $24.9 \mathrm{~kg} / \mathrm{m}^{2}$. The majority of the subjects' blood pressure is also high.

Table 2 shows that there is no confounding variable that has a significantly different effect on the Group I-II and III-IV functional HF groups. Aldosterone levels also did not show a significant difference between the group NYHA I-II functional HF group and the NYHA Class III-IV functional HF group.

\section{Discussion}

ACEI drugs work by inhibiting the activity of ACE in converting AT1 to AT2 and inhibiting the degradation of bradykinin, with the result of reducing peripheral resistance and ultimately lowering blood pressure. In this study, aldosterone levels remained high in both groups despite the use of ACEls or ARBs [11], [12], [13], [14], [15]. However, suppression of ANG-II production and serum aldosterone secretion 
Table 1: Baseline characteristics

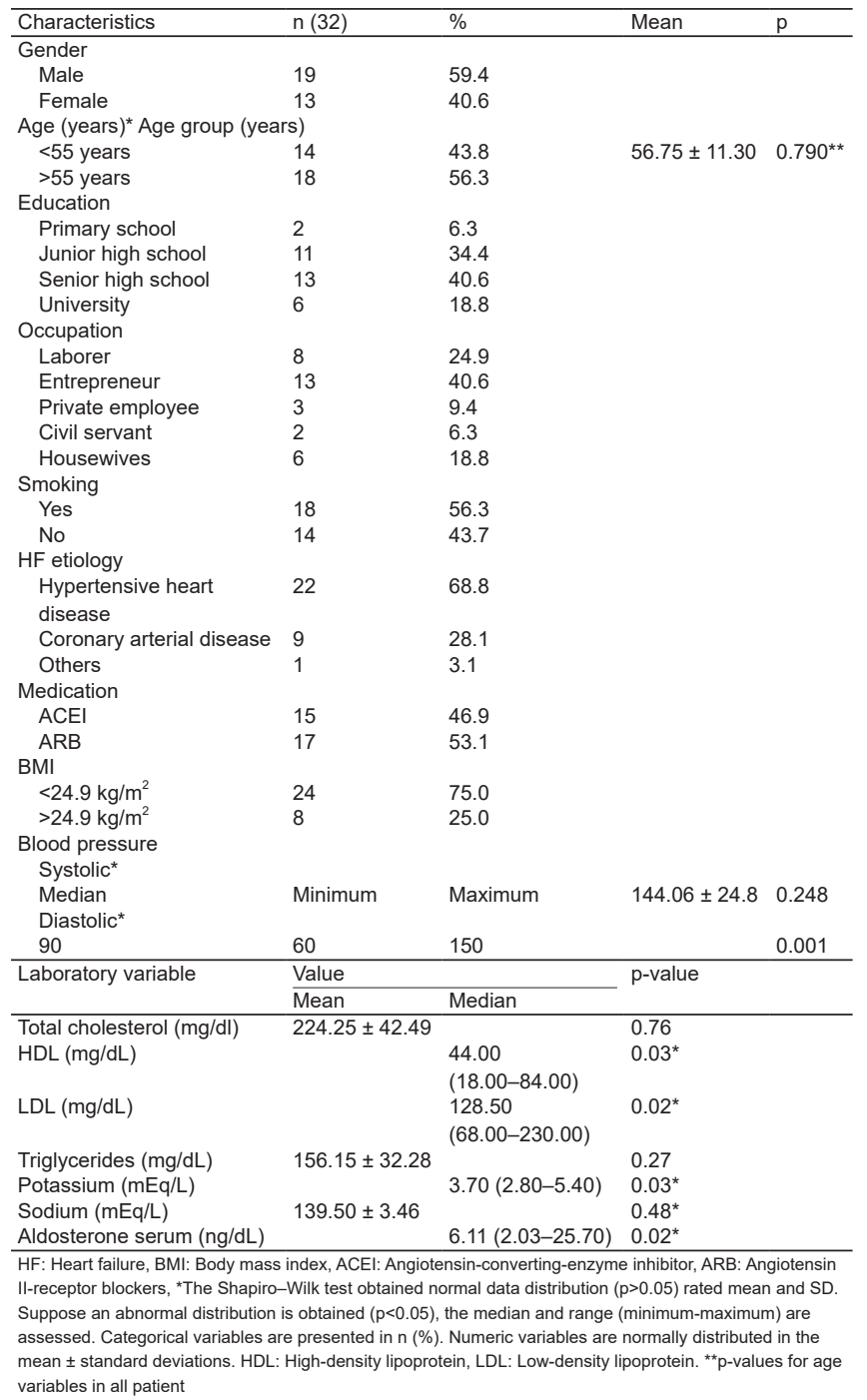

by ACEls and ARBs cannot be sustained even with long-term treatment.

At the beginning of treatment, ACEls or ARBs can indeed eliminate most Ang-II from the serum, but in long-term treatment, Ang-II levels will appear and be re-measured. This situation is called "Ang-II reactivation" and this is associated with a poor prognosis. This is due to ACEls and ARBs unable to inhibit the production of Ang-II produced by other pathways, namely non-renin and nonACE lines. The continued formation of Ang-II means that it will also continue to stimulate aldosterone secretion. This phenomenon is considered as one of the fixed mechanisms of cardiovascularcomplications [16],[17],[18], [19], [20],[21], [22]. ACEls are not able to suppress ACE activity and serum aldosterone secretion in the long term; this may be due to increased serum potassium levels. It has been explained that potassium levels previously, together with AT2 synergistically stimulate serum aldosterone production [23]. The above phenomena might occur in patient with Class I-II and Class III-IV functional HV who have consumed ACEls or ARBs in this study. The use of ACE with ARB in the long term was unable to suppress Ang-II activity, and aldosterone secretion might be related
Table 2: Relationships between variables with HF

\begin{tabular}{|c|c|c|c|c|c|c|}
\hline Variables & & \multicolumn{2}{|c|}{ NYHA Class I-II } & \multicolumn{2}{|c|}{ NYHA Class III-IV } & \multirow[t]{2}{*}{$\mathrm{p}$} \\
\hline Gender & & $\mathrm{n}$ & $\%$ & $\mathrm{n}$ & $\%$ & \\
\hline Male & & 7 & 43.8 & 11 & 68.8 & $0.14^{*}$ \\
\hline Female & & 9 & 56.3 & 5 & 31.3 & \\
\hline \multicolumn{7}{|l|}{ Age } \\
\hline$<55$ years & & 10 & 62.5 & 4 & 25 & $0.45^{*}$ \\
\hline$>55$ years & & 6 & 37.5 & 12 & 75 & \\
\hline \multicolumn{7}{|l|}{ Medication } \\
\hline ACEI & & 8 & 50 & 7 & 43.8 & $0.72^{*}$ \\
\hline ARB & & 8 & 50 & 9 & 56.3 & \\
\hline \multicolumn{7}{|l|}{ HF etiology } \\
\hline HHD & & 13 & 81.3 & 9 & 56.3 & $0.69^{\star *}$ \\
\hline CAD & & 3 & 18.8 & 6 & 37.5 & \\
\hline Others & & 0 & 0 & 1 & 6.3 & \\
\hline \multicolumn{7}{|l|}{ Dyslipidemia } \\
\hline Yes & & 14 & 87.5 & 10 & 62.5 & $0.22^{\star \star \star}$ \\
\hline No & & 2 & 12.5 & 6 & 37.5 & \\
\hline \multicolumn{7}{|l|}{ Smoking } \\
\hline Yes & & 7 & 43.8 & 11 & 68.8 & $0.15^{*}$ \\
\hline No & & 9 & 56.3 & 5 & 31.3 & \\
\hline Aldosterone & Functional Class & \multicolumn{2}{|c|}{$\begin{array}{l}\text { Functional Class } \\
\text { III-IV }(n=16)\end{array}$} & \multicolumn{2}{|l|}{$p$-value } & \\
\hline $\begin{array}{l}\text { variable } \\
\text { Aldosterone level }\end{array}$ & $\begin{array}{l}I-I I(n=16) \\
8.06 \pm 3.92\end{array}$ & \multicolumn{2}{|c|}{$5.31(2.03-25.70)$} & \multicolumn{2}{|l|}{$0.445^{\#}$} & \\
\hline
\end{tabular}

to changes in the responsive mechanisms of various receptors involved with RAAS itself.

The results of this study are in line with a survey conducted by Kobayashi et al. in 2020, which stated that aldosterone did not play a role in clinical improvement of HF patients, improved therapeutic response, and had no effect on improving patient outcomes with HF [24]. This study is one of the researches that compared the aldosterone levels of patients with HF categories NYHA I-II and NYHA III-IV in an Asian population. The limitation of this study is the limited number of research samples.

\section{Conclusion}

Serum aldosterone levels in patients with Class I-II functional HF and those with Class III-IV functional HF who consumed ACEls or ARBs were not significantly different.

\section{Acknowledgment}

The authors would express their sincere gratitude to the Medical Research Unit of the Faculty of Medicine, Universitas Sriwijaya, Palembang, Indonesia.

\section{References}

1. Julie HB, Anderson ME. Aldosterone and cardiovascular disease: The heart of the matter. In: Trends Endocrinol Metabolism. $1^{\text {st }}$ ed. Chicago: Northwestern University; 2013. p. 
21-30.

2. Yancy CW, Jessup M, Bozkurt M, Buttler J, Casey D Jr., Colvin MM, et al. 2017 ACCF/AHA/HFSA focused update of the 2013 ACCF/AHA guideline for the management of heart failure: $A$ report of the American college of cardiology foundation/American heart association task force on clinical practice guidelines and the heart failure society of America. Circulation. 2017;136:e13761. https://doi.org/10.1161/cir.0000000000000460 PMid:28455343

3. Borer JS, Bohm M, Ford I, Komajda M, Tavazzi L,Sendon JL, et al. Effect of ivabradine on recurrent hospitalization for worsening heart failure in patients with chronic systolic heart failure: The SHIFT study. Eur Heart J. 2016;33(22):2813-20. https://doi.org/10.1093/eurheartj/ehs259

PMid:22927555

4. Braunwald E. Heart failure: State of the art paper. J Am Coll Cardiol. 2013;1(1):1-20.

5. Dobre D, Borer JS, Fox K, Swedberg K, Adams KF, Cleland JG et al. Heart rate: A prognostic factor and therapeutic target in chronic heart failure. The distinct roles of drugs with heart ratelowering properties. Eur J Heart Fail. 2014;16(1):76-85. https:// doi.org/10.1093/eurjhf/hft129

PMid:23928650

6. McMurray JJ, Adamopoulos S, Anker SD, Auricchio A, Böhm M Dickstein $\mathrm{K}$, et al. ESC guidelines for the diagnosis and treatment of acute and chronic heart failure 2012: The task force for the diagnosis and treatment of acute and chronic heart failure 2012 of the European society of cardiology. Develop in collaboration with the heart failure association. Eur J Heart. 2012;14(8):80369. https://doi.org/10.3410/f.718489795.793497182

7. Connell JM, Davies E. The new biology of aldosterone. J Endocrinol. 2005;186(1):1-20.

PMid:16002531

8. McKelvie RS, Rouleau JL, White M, Afzal R, Young JB, Maggioni AP, et al. Comparative impact of enalapril, candesartan or metoprolol alone or in combination on ventricular remodelling in patients with congestive heart failure. Eur Heart J. 2013;24(19):1727-34. https://doi.org/10.1016/ s0195-668x(03)00477-9

PMid:14522567

9. Bassett MH, White PC, Rainey WE. The regulation of aldosterone synthase expression. Mol Cell Endocrinol. 2014;21(7):67-74. PMid:15134803

10. Lip GYH, Gibbs CR, Beevers DG. ABC of heart failure: Aetiology. BMJ. 2000;320(7227):104-7. https://doi.org/10.1136/ sbmj.000219 PMid:10625270

11. Izzo JL, Gradman AH. Mechanism and management of hypertensive heart disease: From left ventricular hypertrophy to heart failure. Med Clin North Am. 2014;88:1257-71. https://doi. org/10.1016/j.mcna.2004.06.002

PMid:15331316
12. Figueroa MS, Peters J. Congestive heart failure: Diagnosis, pathophysiology, therapy, and implications for respiratory care. In: Respir Care. $3^{\text {rd }}$ ed. Texas: The University of Texas Health Science Center; 2016. p. 403-12.

13. Rodeheffer R. Cardiomyopathies in the adult (dilated, hypertrophic, and restrictive). In: Dec GW, editor. Heart Failure a Comprehensive Guide to Diagnosis and Treatment. New York: Marcel Dekker; 2015. p. 137-56. https://doi.org/10.1201/ b14176-11

14. Jackson G, Gibbs CR, Davies MK, Lip GY. ABC of heart failure: Pathophysiology. BMJ. 2010;320(7228):167-70. https://doi. org/10.1136/bmj.320.7228.167

PMid:10634740

15. McNamara DM. Neurohormonal and cytokine activation in heart failure. In: Dec GW, editor. Heart Failure a Comprehensive Guide to Diagnosis and Treatment. New York: Marcel Dekker; 2015. p. 117-36. https://doi.org/10.1201/b14176-10

16. Santoso A, Erwinanto, Munawar M, Suryawan R, Rifqi S, Soerianata S. Diagnosis and treatment of acute heart failure. Jakarta: EGC; 2007. p. 120-35.

17. Mann DL, Murali C. Heart failure: Pathophysiology and diagnosis. In: Harrison's Principles of Internal Medicine. $19^{\text {th }}$ ed. New York: McGraw- Hill; 2015. p. 1500-6.

18. King M, Kingery J, Casey B. Diagnosis and Evaluation of Heart Failure. $2^{\text {nd }}$ ed. Kentucky, New York: American Academy of Family Physician, McGraw-Hill; 2012. p. 1020-48.

19. Yang M. Aldosterone. In: Researcher. $1^{\text {st }}$ ed. New York: McGrawHill; 2009. p. 89-93.

20. Tomaschitz A, Pilz S, Ritz E, Meinitzer A, Boehm BO, Marz W. Plasma aldosterone levels are associated with increased cardiovascular mortality: The Ludwigshafen Risk and Cardiovascular Health (LURIC) study. Eur Heart J. 2010;31(10):1237-47. https://doi.org/10.1093/eurheartj/ ehq019 PMid:20200015

21. Murin J. Cardiovascular effect of aldosterone. Bratisl Lek Listy. 2015;106(1):3-19.

22. Ruster C, Wolf G. Renin angiotensin aldosterone system and progression of renal disease. J Am Soc Nephrol. 2006;17(11):2985-91. https://doi.org/10.1681/asn.2006040356 PMid:17035613

23. Atlas SA. The renin-angiotensin aldosterone system: Pathophysiological role and pharmacologic inhibition. J Manag Care Pharm. 2007;13(Suppl B):9-20. https://doi.org/10.18553/ jmcp.2007.13.s8-b.9 PMid:17970613

24. Kobayashi M, Stienen S, Maaten J, Dickstein K, Samani NJ, Lang CC, et al. Clinical determinants and prognostic imlications of renin and aldosterone in patients with symptomatic heart failure. ESC Heart Failure. 2020;7:953-63. https://doi. org/10.1002/ehf2.12634

PMid:32167681 